\title{
2.4.3. Uniwersalne projektowanie zajęć jako droga do zaspokajania zróżnicowanych potrzeb edukacyjnych
}

DOI: $10.47050 / 65591838.208-217$

Katarzyna Cichocka-Segiet, Piotr Mostowski, Paweł Rutkowski

Początki projektowania uniwersalnego związane są ściśle z dziedziną architektury. Podstawowym założeniem zaproponowanej przez architekta Ronalda L. Mace'a koncepcji projektowania globalnego było uczynienie otoczenia dostępnym dla jak najszerszej grupy użytkowników. Plan odpowiadający takim standardom nie wymaga dalszych adaptacji, zachowując jednocześnie walory estetyczne. Warto podkreślić, że uwzględnienie potrzeb konkretnej grupy użytkowników często przynosi zysk również innym (np. obniżone krawężniki są udogodnieniem nie tylko dla ludzi poruszających się na wózkach, lecz także dla osób starszych, dostawców). W latach 90. XX wieku w Centrum Projektowania Uniwersalnego (Uniwersytet Karoliny Północnej) opracowano podstawowe zasady opisanego wyżej podejścia do projektowania, dotyczące m.in. równego dostępu, elastyczności, prostoty i niewyszukania, odpowiedniego środowiska, zrozumiałości informacji czy ograniczenia koniecznego wysiłku fizycznego (dokładny opis tych wytycznych wraz z przykładami: Connell i in. 1997). Z czasem założenia projektowania uniwersalnego zaczęły przenikać do obszarów takich jak wzornictwo przemysłowe, interfejsy komputerowe, strony i serwisy internetowe, technologie komunikacyjne itp. (Adaszyńska 2017, s. 16-17). W latach 90. ubiegłego wieku zaczęto również używać określenia „projektowanie uniwersalne w nauczaniu” (UDL, Universal Design for Learning). Głównym podmiotem stojącym za przeniesieniem idei projektowania uniwersalnego na grunt edukacji była amerykańska organizacja CAST (Center for Applied Special Technology) (Fedorowicz 2007, s. 401). UDL jest modelem opracowywania procesu nauczania w taki sposób, aby uwzględniał on potrzeby jak 
największej grupy odbiorców. Założenia UDL oparte są na wnioskach z badań pedagogicznych, psychologicznych, a nawet neurobiologicznych (por. np. Domagała-Zyśk 2015, s. 554). Podstawą UDL jest konstatacja, że ludzie uczą się na różne sposoby i różnorodność ta powinna być uwzględniona w środowisku edukacyjnym od początku nauki (Gronneberg, Johnston 2015). Wszyscy powinni móc w pełni uczestniczyć w procesie dydaktycznym bez obniżania jego standardów. Chociaż UDL z założenia dotyczy ogółu uczniów, jest ono szczególnie istotne dla tych ze specjalnymi potrzebami edukacyjnymi. Implementacja tego rozwiązania jest zatem właściwie nieodzowna w modelu edukacji włączającej.

Jak pokazuje m.in. opracowanie przygotowane przez Teaching Excellence in Adult Literacy Center (TEAL 2010), uniwersalne projektowanie w nauczaniu wymaga stosowania różnorodnych i elastycznych metod:

$\rightarrow$ prezentacji informacji lub umożliwienia dostępu do nich (nacisk na to, CZEGO uczymy),

$\rightarrow$ planowania i wykonywania zadań (nacisk na to, JAK uczymy),

$\rightarrow$ angażowania uczniów w proces uczenia się (nacisk na to, DLACZEGO uczymy).

Te trzy aspekty przekładają się na następujące oczekiwania kierowane pod adresem procesu dydaktycznego, tj. na wiele sposobów:

$\rightarrow$ przedstawiania (różne metody prezentowania informacji, zapewnienie wsparcia),

$\rightarrow$ działania i ekspresji (dostarczanie uczącym się alternatywnych sposobów prezentowania swoich umiejętności i wiedzy),

$\rightarrow$ angażowania (wykorzystanie zainteresowań uczniów przy wyborze treści i narzędzi edukacyjnych, motywowanie uczniów poprzez dostosowywanie poziomu wyzwań).

Tabela 1 przedstawia listę wytycznych uniwersalnego projektowania w nauczaniu opracowanych przez CAST (2018a). W polskim tłumaczeniu zastosowaliśmy bezpośredni zwrot w drugiej osobie liczby pojedynczej, dzięki czemu wytyczne zachowują charakter instrukcji i mogą służyć jako lista kontrolna. Zapisy na liście mają charaktery syntetyczny, gdyż ich celem jest zasygnalizowanie poszczególnych zagadnień. Szczegółowe opisy dotyczące każdego z punktów wraz z przykładami można znaleźć na stronie internetowej UDL Guidelines'. 
Tabela 1. Wytyczne uniwersalnego projektowania w nauczaniu

\begin{tabular}{|c|c|c|}
\hline $\begin{array}{l}\text { I. ZAPEWNIAJ ZRÓŻNICOWANE } \\
\text { SPOSOBY PREZENTOWANIA TREŚCI }\end{array}$ & $\begin{array}{l}\text { II. ZAPEWNIAJ WIELE MOŻLIWOŚCI } \\
\text { DZIALANIA I EKSPRESJI }\end{array}$ & $\begin{array}{l}\text { III. ZAPEWNIAJ WIELE SPOSOBÓW } \\
\text { ANGAŻOWANIA }\end{array}$ \\
\hline $\begin{array}{l}\text { 1. Umożliwiaj wybór w zakre- } \\
\text { sie percepcji: } \\
\text { 1.1. Zapewniaj możliwości } \\
\text { dostosowań w zakresie } \\
\text { wzrokowego odbioru informacji, } \\
\text { 1.2. Udostępniaj alternatywę } \\
\text { dla treści dźwiękowych, } \\
\text { 1.3. Udostępniaj alternatywę } \\
\text { dla treści wizualnych. }\end{array}$ & $\begin{array}{l}\text { 4. Dawaj wybór w zakresie } \\
\text { fizycznego działania: } \\
\text { 4.1. Różnicuj metody reagowa- } \\
\text { nia i nawigowania, } \\
\text { 4.2. Optymalizuj dostęp } \\
\text { do narzędzi i technologii } \\
\text { wspomagających. }\end{array}$ & $\begin{array}{l}\text { 7. Stwarzaj warunki do roz- } \\
\text { budzania zainteresowania: } \\
\text { 7.1. Wspieraj indywidualne } \\
\text { wybory i autonomię, } \\
\text { 7.2. Dbaj o istotność, warto- } \\
\text { ściowość i autentyczność, } \\
\text { 7.3. Minimalizuj zagrożenia } \\
\text { i dystraktory. }\end{array}$ \\
\hline $\begin{array}{l}\text { 2. Zapewniaj różne możliwości } \\
\text { w zakresie języka, wyrażeń } \\
\text { matematycznych i symboli: } \\
\text { 2.1. Wyjaśniaj słownictwo } \\
\text { i symbole, } \\
2.2 \text { Objaśniaj składnię i struktu- } \\
\text { rę tekstu, } \\
\text { 2.3. Wspieraj odczytywanie } \\
\text { tekstu, notacji matematycznej } \\
\text { i symboli, } \\
\text { 2.4. Zachęcaj do rozwijania } \\
\text { komunikacji międzyjęzykowej, } \\
\text { 2.5. Wykorzystuj różne media } \\
\text { do ilustrowania treści. }\end{array}$ & $\begin{array}{l}\text { 5. Zapewniaj zróżnicowa- } \\
\text { ne możliwości ekspresji } \\
\text { i komunikacji: } \\
\text { 5.1. Korzystaj z różnych } \\
\text { mediów do komunikacji, } \\
\text { 5.2. Korzystaj z różnych } \\
\text { narzędzi do tworzenia } \\
\text { i łączenia komunikatów, } \\
\text { 5.3. Rozwijaj umiejętności } \\
\text { na podstawie praktyki. }\end{array}$ & $\begin{array}{l}\text { 8. Zapewniaj możliwość } \\
\text { trwałego wysiłku i budowa- } \\
\text { nia wytrwałości: } \\
\text { 8.1. Uwydatniaj cele } \\
\text { i zadania, } \\
\text { 8.2. Optymalizuj wyzwania } \\
\text { przez różnicowanie oczeki- } \\
\text { wań i dostępnych zasobów, } \\
\text { 8.3. Wspieraj współpracę } \\
\text { i twórz społeczność, } \\
\text { 8.4. Zwiększaj liczbę infor- } \\
\text { macji zwrotnych. }\end{array}$ \\
\hline $\begin{array}{l}\text { 3. Zapewniaj różne możliwości } \\
\text { w zakresie rozumienia: } \\
\text { 3.1. Aktywizuj i poszerzaj } \\
\text { wiedzę ogólną, } \\
\text { 3.2. Podkreślaj wzorce, najważ- } \\
\text { niejsze cechy, nadrzędne idee } \\
\text { i istniejące relacje, } \\
\text { 3.3. Udzielaj wskazówek doty- } \\
\text { czących przetwarzania i wizuali- } \\
\text { zacji informacji oraz operowania } \\
\text { nimi. }\end{array}$ & $\begin{array}{l}\text { 6. Zapewniaj różne moż- } \\
\text { liwości w zakresie funk- } \\
\text { cji wykonawczych: } \\
\text { 6.1. Udzielaj wskazówek doty- } \\
\text { czących właściwego wybiera- } \\
\text { nia celów, } \\
\text { 6.2. Wspieraj rozwijanie strate- } \\
\text { gii i planowanie, } \\
\text { 6.3. Pomagaj w zarządzaniu } \\
\text { informacją i zasobami, } \\
\text { 6.4. Zwiększaj możliwość } \\
\text { monitorowania postępów. }\end{array}$ & $\begin{array}{l}\text { 9. Zapewniaj warun- } \\
\text { ki samoregulacji: } \\
\text { 9.1. Promuj motywujące } \\
\text { oczekiwania i przekonania, } \\
\text { 9.2. Wspieraj indywidualne } \\
\text { umiejętności i strategie } \\
\text { rozwiązywania problemów, } \\
\text { 9.3. Zachęcaj do samooceny } \\
\text { i autorefleksji. }\end{array}$ \\
\hline Uczniowie zaradni i kompetentni & $\begin{array}{l}\text { Uczniowie planujący } \\
\text { i ukierunkowani na cel }\end{array}$ & $\begin{array}{l}\text { Uczniowie zmotywowani } \\
\text { i świadomi celu }\end{array}$ \\
\hline
\end{tabular}

Źródło: CAST 2018a ([za: Rao, Meo 2016, s. 2; tłumaczenie i opracowanie własne]).

Listę podzielono zgodnie z trzema głównymi zasadami uniwersalnego projektowania w nauczaniu. Każda kategoria powiązana jest z odrębnymi sieciami neuronowymi aktywnymi w mózgu i odpowiedzialnymi kolejno za zrozumienie, planowanie strategiczne i afektywność (CAST 2018b). Tym samym UDL uwzględnia sposób, w jaki nasz mózg przyswaja nowe informacje, przetwarza je i zapamiętuje. 
Trzydzieści jeden punktów pogrupowanych w dziewięciu kategoriach i trzech zestawach pozwala nauczycielowi już na etapie planowania zajęć uwzględnić zróżnicowane potrzeby uczniów, a tym samym stworzyć w pełni inkluzywne środowisko edukacyjne. Przeprowadzone dotychczas badania skuteczności UDL pokazują, że uczniowie biorący udział w procesie nauczania uwzględniającym te wytyczne uzyskują lepsze wyniki oraz są bardziej zmotywowani i zaangażowani (Rao, Meo 2016, s. 3). Kluczowe wydaje się w tym kontekście postrzeganie kształcenia (nauczania/uczenia się) jako procesu nabywania wiedzy, umiejętności i kompetencji.

Przygotowywanie zajęć dydaktycznych z uwzględnieniem uniwersalnego projektowania w nauczaniu należy rozbić na dwa etapy (Rao, Meo 2016, s. 4). Pierwszy z nich to analiza zapisów zawartych w podstawie programowej i w szczegółowych planach nauczania, dotycząca wiedzy i umiejętności, które powinien przyswoić uczeń. Ważne jest, aby maksymalnie doprecyzować użyte w tych dokumentach sformułowania o charakterze ogólnym. Dzięki właściwemu zidentyfikowaniu istotnych umiejętności i wiedzy możemy przejść do szczegółowego planowania lekcji. Identyfikacja wiedzy i umiejętności wiąże się ściśle z procesem diagnozy edukacyjnej, rozumianej jako „poszukiwanie odpowiedzi na pytanie: jak przebiega proces (ten, który stanowi podstawę działań mających przynieść określony wynik), jakie ewentualnie pojawiają się zaburzenia w przebiegu tego procesu" (Hajnicz 2010, s. 34). Dopiero w wyniku diagnozy sformułowane może zostać zadanie „postrzegane z punktu widzenia procesów, które angażuje, a nie z punktu widzenia wyniku, do którego ma prowadzić" (tamże, s. 35). Podjęcie opisanych tu działań jest punktem wyjścia do szczegółowego przygotowania lekcji. UDL można wykorzystać przy planowaniu każdego elementu związanego z organizacją i przebiegiem zajęć. W literaturze przedmiotu wyróżnia się często cztery główne komponenty lekcji (por. Rao, Meo 2016, s. 5): określenie celów zajęć, które odpowiadają podstawie programowej, opracowanie strategii instruktażowej (metody), wybór zasobów imateriałów oraz ocenianie postępów i wyników uczniów. Przy analizie każdego z tych elementów można posłużyć się odpowiednimi pytaniami pomocniczymi (zob. tabela 2). 
Tabela 2. Zastosowanie UDL dla wybranych komponentów lekcji

\begin{tabular}{l|l} 
KOMPONENT LEKCJI & \multicolumn{1}{|c}{ PYTANIA POMOCNE PRZY PROJEKTOWANIU Z WYKORZYSTANIEM UDL } \\
\hline Cele & $\begin{array}{l}\text { Jakie umiejętności i wiedzę uczniowie powinni przyswoić (zgodnie z wymoga- } \\
\text { mi podstawy programowej)? }\end{array}$ \\
\hline Ocenianie & Jak uczniowie mogą pokazać, że osiągnęli wyznaczone cele? \\
\hline Metody & $\begin{array}{l}\text { Jakie wsparcie można zapewnić w ramach instruowania, aby uczniowie } \\
\text { przyswoili materiał i zaprezentowali swoją wiedzę? }\end{array}$ \\
\hline Materiały & $\begin{array}{l}\text { Jakie zasoby, materiały i narzędzia mogą zostać użyte, aby zapewnić zróżni- } \\
\text { cowane sposoby prezentowania informacji oraz zainteresować przedstawia- } \\
\text { nymi treściami? }\end{array}$
\end{tabular}

Źródło: Rao, Meo 2016, s. 5 (tłumaczenie i opracowanie własne).

Wszystkie kroki projektowania zajęć z wykorzystaniem UDL przedstawia rys. 1. Szczegółowy opis każdego z nich można znaleźć w pracy Rao, Meo (2016).

Rysunek 1. Cykl projektowania zajęć z wykorzystaniem UDL

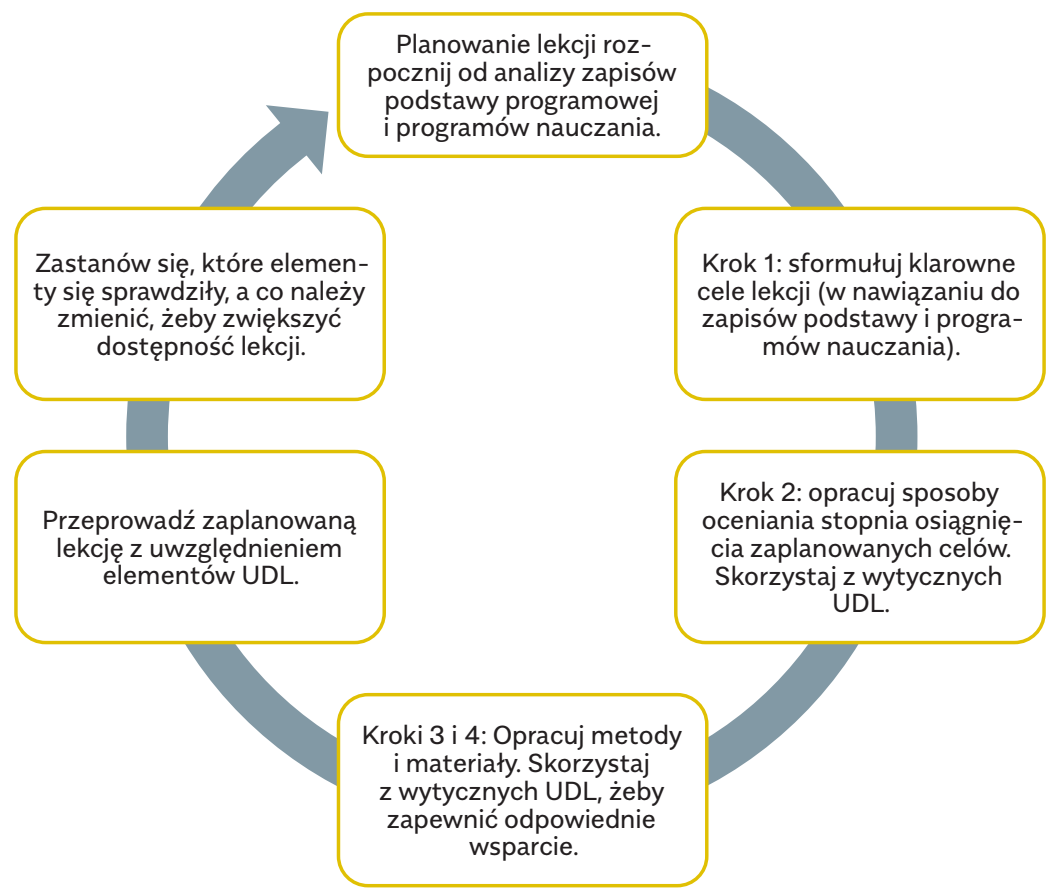

Źródło: Rao, Meo 2016, s. 5 (tłumaczenie i opracowanie własne). 
Zgodnie ze swoją nazwą projektowanie uniwersalne w nauczaniu może być stosowane w każdym środowisku edukacyjnym. Powinno ono prowadzić do zaspokojenia potrzeb wynikających ze zróżnicowań w zakresie statusu socjoekonomicznego, kulturowego i zdrowotnego uczniów. Nie zawsze udaje się ten postulat w pełni zrealizować, ale należy dokładać starań, by beneficjentów było możliwie wielu, a najlepiej, by korzyści odnieśli wszyscy uczestnicy procesu nauczania. Chociaż w założeniach UDL nie precyzuje się docelowej grupy, to z reguły podejście to kojarzone jest z osobami ze specjalnymi potrzebami edukacyjnymi, często z zawężeniem do uczniów z niepełnosprawnościami. Posiadają oni orzeczenie o potrzebie kształcenia specjalnego, wydane z uwagi na niepełnosprawność przez zespół orzekający działający w publicznej poradni psychologiczno-pedagogicznej. Rozporządzenie Ministra Edukacji Narodowej z dnia 9 sierpnia 2017 r. w sprawie warunków organizowania kształcenia, wychowania i opieki dla dzieci i młodzieży niepełnosprawnych, niedostosowanych społecznie i zagrożonych niedostosowaniem społecznym (Dz.U. z 2017 r. poz. 1578) określa, że kształcenie specjalne organizuje się dla następujących grup uczniów:

$\rightarrow$ niesłyszących,

$\rightarrow$ słabosłyszących,

$\rightarrow$ niewidomych,

$\rightarrow$ słabowidzących,

$\rightarrow$ z niepełnosprawnością ruchową (w tym z afazją),

$\rightarrow$ z niepełnosprawnością intelektualną $w$ stopniu lekkim, umiarkowanym lub znacznym,

$\rightarrow$ z autyzmem, $w$ tym z zespołem Aspergera,

$\rightarrow \quad z$ niepełnosprawnościami sprzężonymi.

Trudno wyobrazić sobie stworzenie jednolitej listy potrzeb edukacyjnych, która dotyczyłaby każdej z wymienionych grup. Na przykład uczniowie głusi posługujący się polskim językiem migowym (PJM) mają zupełnie inne potrzeby komunikacyjne niż uczniowie niewidomi, których językiem rodzimym jest polszczyzna. Udogodnienia przestrzenne dla uczniów z niepełnosprawnością ruchową nie są z kolei niezbędne dla pozostałych grup wymienionych wyżej. Warto jednak pamiętać o jednym z kluczowych założeń projektowania uniwersalnego - to, co jest dobre dla konkretnych odbiorców, może przynieść korzyści wszystkim. Upraszczanie złożonych struktur składniowych w tekście 
- przy zachowaniu jego warstwy merytorycznej - będzie ułatwiało lekturę zarówno uczniom głuchym, jak i osobom z niepełnosprawnością intelektualną w stopniu lekkim czy z trudnościami w porozumiewaniu się słownym (określanym także mianem dzieci ze złożonymi potrzebami komunikacyjnymi - complex communication needs). Obszerna lista wytycznych przedstawionych w tabeli 1 obejmuje wszystkie aspekty procesu nauczania/uczenia się. Korzystając z tych wskazówek przy planowaniu lekcji, mamy pewność, że uwzględnione zostaną różne sfery - nie tylko w zakresie metod i treści, lecz również motywacji i nastawienia uczącego się. Nie zawsze jest jednak możliwe zaprojektowanie zajęć całkowicie dostępnych dla wszystkich, dlatego UDL dopuszcza w uzasadnionych przypadkach stosowanie dodatkowych pomocy, np. odpowiednio zaadaptowanych materiałów edukacyjnych lub technologii wspomagających (takich jak powiększalnik, wskaźnik ustny lub nagłowny, czytnik ekranu czy urządzenia umożliwiające komunikowanie się osobom ze złożonymi potrzebami komunikacyjnymi).

Warto w tym miejscu zwrócić uwagę, że uczeń ze specjalnymi potrzebami edukacyjnymi jest zwykle postrzegany przez pryzmat konkretnych zaburzeń, co nie zawsze pozwala na właściwą ocenę jego możliwości. Co oczywiste, istotne jest zapewnienie dziecku odpowiednich warunków i narzędzi, jednak metodyka pracy nie musi łączyć się bezpośrednio z rozpoznaną trudnością rozwojową. Kluczową rolę odgrywa właściwe zidentyfikowanie rzeczywistych możliwości i kompetencji ucznia, czyli określenie - w sposób funkcjonalny - posiadanych przez niego wiadomości i umiejętności, które powinny być rozwijane i stanowić bazę dla dalszego postępowania edukacyjnego. Każde proponowane w procesie nauczania zadanie składa się z wielu etapów, które należy pokonać, by uzyskać określony wynik (osiągnąć zamierzony cel). Każdy uczeń - zarówno rozwijający się prawidłowo, jak i mający rozpoznane specjalne potrzeby edukacyjne - może nie poradzić sobie z realizacją oczekiwanej czynności. Przystępując do uniwersalnego projektowania zajęć, należy zatem mieć świadomość, jakimi kompetencjami szczegółowymi musi dysponować uczeń, aby dane zadanie zostało zrealizowane. Na przykład rozwiązanie zadania z tekstem realizowanego na lekcji matematyki wymaga od ucznia m.in.:

$\rightarrow$ przeczytania i zrozumienia treści (a zatem posługiwania się słowami takimi jak „suma”, „razem”), 
$\rightarrow$ posiadania ukształtowanego pojęcia liczb w zakresie określonym w zadaniu,

$\rightarrow$ określenia danych potrzebnych do wykonania obliczeń,

$\rightarrow$ znajomości znaków matematycznych, które muszą zostać użyte przy zapisie działania,

$\rightarrow$ wiedzy o tym, że działanie matematyczne musi zostać zapisane według ściśle określonego wzorca (liczba - znak - liczba - znak - liczba, od strony lewej do prawej),

$\rightarrow$ umiejętności wykonania obliczenia,

$\rightarrow$ sformułowania i zapisania odpowiedzi na postawione pytanie.

U każdego ucznia mogą pojawić się trudności na jednym z etapów i nie muszą one wynikać z niepełnosprawności. Przy projektowaniu zadania ważne jest zatem poddanie analizie wszystkich składowych potrzebnych do jego wykonania. Wynikiem tego sposobu myślenia w zakresie projektowania może być stworzenie materiałów zaadaptowanych do potrzeb uczniów ze specjalnymi potrzebami edukacyjnymi, które różnią się od materiałów bazowych nie na poziomie treści programowych, lecz w obszarze metodyczno-technicznym. W wielu wypadkach nawet nieznaczna modyfikacja oryginału wystarcza, by uczeń ze specjalnymi potrzebami edukacyjnymi samodzielnie zrealizował oczekiwaną aktywność.

Przykładem materiałów, które mogą być wykorzystane przy projektowaniu i prowadzeniu zajęć w paradygmacie UDL, są adaptacje podręczników szkolnych wykonywane od 2014 r. przez Pracownię Lingwistyki Migowej na Wydziale Polonistyki Uniwersytetu Warszawskiego (por. Rutkowski, Mostowski 2017; 2018). Dotychczas do potrzeb edukacyjnych uczniów mających trudności w uczeniu się i (lub) komunikowaniu się, w tym niesłyszących, słabosłyszących, z niepełnosprawnością intelektualną, autyzmem i afazją, dostosowane zostały m.in. podręczniki do edukacji wczesnoszkolnej oraz do historii, matematyki, języka polskiego i przyrody dla klasy IV szkoły podstawowej, podręczniki do matematyki, biologii, geografii, historii i języka polskiego dla klasy V, podręczniki do wiedzy o społeczeństwie, biologii, chemii, fizyki, geografii, historii, matematyki i języka polskiego dla klasy VII, a także podręczniki do biologii, chemii, fizyki, geografii, historii, matematyki i języka polskiego dla klasy VIII. Pakiet materiałów do edukacji wczesnoszkolnej składa się z: 
$\rightarrow$ adaptacji oryginalnego podręcznika (przeredagowane treści poleceń, ilustracje zmodyfikowane pod kątem dostępności percepcyjnej),

$\rightarrow$ wersji multimedialnej (treści zaadaptowanej papierowej wersji podręcznika, uzupełnione o tłumaczenie na polski język migowy i znaki graficzne systemu PCS - picture communication symbols),

$\rightarrow$ zeszytu piktogramów (tabele z piktogramami PCS odpowiadającymi słownictwu poszczególnych lekcji oraz wybrane pytania i polecenia oddane tymi symbolami),

$\rightarrow$ poradnika dla nauczyciela (książka ze wskazówkami metodycznymi oraz dokładnym opisem dokonanych modyfikacji),

$\rightarrow$ zeszytu kart pracy (ćwiczenia utrwalające wiedzę i umiejętności określone w podstawie programowej),

$\rightarrow$ książek z serii "Język polski na plus" i "Nasz język polski” (ćwiczenia wspomagające nabywanie przez uczniów kompetencji komunikacyjnych w języku polskim).

W skład pakietu materiałów przygotowanych do każdego z podręczników do klas wyższych niż III wchodzą z kolei:

$\rightarrow$ zaadaptowane teksty dotyczące poszczególnych zagadnień przedmiotowych,

$\rightarrow$ ilustracje zmodyfikowane pod kątem dostępności percepcyjnej,

$\rightarrow$ tablice ze znakami graficznymi systemu PCS,

$\rightarrow$ filmy z tłumaczeniem na polski język migowy.

Szczegółowe informacje na temat zaadaptowanych tytułów można znaleźć na stronach internetowych Ministerstwa Edukacji Narodowej2 lub Ośrodka Rozwoju Edukacji ${ }^{3}$.

Opisane adaptacje były zaplanowane i przeprowadzone zgodnie z kluczowymi założeniami paradygmatu UDL. Każda treść została przedstawiona na kilka różnych sposobów (zaadaptowany tekst polski, tłumaczenie na polski język migowy, zapis znakami graficznymi systemu PCS) oraz w różnych formatach (wersja do druku, elektroniczna, multimedialna). Warstwa tekstowa była modyfikowana w celu

2 bit.ly/2WXjomY [dostęp: 23.07.2019].

3 bit.ly/2EZA0jA [dostęp: 23.07.2019]. Większość podręczników jest również dostępna w wersji brajlowskiej oraz w wersji dla uczniów słabowidzących - adaptacje te zostały wykonane przez Biuro ds. Osób Niepełnosprawnych Uniwersytetu Warszawskiego. 
eliminacji nadmiernej złożoności składniowej i trudności leksykalnych, ale z zachowaniem najistotniejszych informacji. Dodatkowo wybrane treści zostały opatrzone objaśnieniami lub ilustracjami pomocniczymi. Zmiany dotyczące warstwy graficznej miały na celu przede wszystkim dostosowanie możliwości jej odbioru do potrzeb psychofizycznych osób ze specjalnymi potrzebami edukacyjnymi. Zgodnie z wytycznymi UDL część modyfikacji dotyczyła zwiększenia zaangażowania uczniów - polecenia w formie bezosobowej zostały więc przekształcone $w$ bezpośrednie zwroty do odbiorcy, zastosowano w nich teksty ułatwiające przyznanie się do niewiedzy, a w przypadku trudniejszych zadań zaoferowana została możliwość wykonania ich prostszego wariantu. Dokładny opis przyjętych rozwiązań zamieszczono w towarzyszących poszczególnym podręcznikom książkach pomocniczych (swoistych poradnikach dla nauczyciela), zawierających materiał informacyjny dotyczący zalecanych sposobów korzystania z adaptacji (zob. m.in. Bajewska-Kołodziejak i in. 2014; 2017).

Zajęcia edukacyjne powinny przystawać do potrzeb wszystkich ich uczestników. Projektowanie takich lekcji bywa niezmiernie trudne. Im mniej homogeniczna grupa odbiorców i bardziej zróżnicowane potrzeby, tym więcej aspektów należy uwzględnić na etapie planowania. Jedną ze sprawdzonych metod tworzenia lekcji "dla wszystkich" jest stosowanie się do zasad projektowania uniwersalnego w nauczaniu (UDL). Wiele prostych wskazówek pozwala należycie dopracować każdy poziom procesu edukacyjnego. Standard ten funkcjonuje od prawie 30 lat, a liczne badania (por. m.in. Rao i in. 2014; Capp 2017) pokazują, że przynosi on korzyści zarówno osobom uczącym się, jak i nauczycielom. Z punktu widzenia uczniów ze specjalnymi potrzebami edukacyjnymi, planowanie zgodne z UDL będzie łatwiejsze do wprowadzenia dzięki wspomnianym bezpłatnym materiałom zaadaptowanym. Jest to z pewnością argument przemawiający za uwzględnieniem UDL w pracy pedagogicznej z uczniami ze specjalnymi potrzebami edukacyjnymi. 